\title{
PERFORMANCE OF EXTERNAL REINFORCED CONCRETE BEAM-COLUMN JOINTS MADE OF HIGH STRENGTH CONCRETE
}

\author{
Ramadan M. A. *, M. M. Ahmed**, Abdel-Mageed M. A. **, \\ and Megahid A. A.*** \\ *Eng.at Qune govnovate, \\ ** Associate professor, Civil Eng. Department, Assiut University, \\ *** Professor, Civil Eng. Department, Assiut University,
}

(Received January 27, 2011 Accepted April 16, 2011)

The integrity of beam-column joints in reinforced concrete $(R C)$ frames, especially in a crucial zone, is essential for the satisfactory performance of the whole structure. Therefore, the behavior of external connections between beams and columns is a significant parameter affecting the performance of such R.C frames. An important influence in this regard is the concrete compressive strength, joint reinforcement and relative stiffness of beam and column in each connection, which is itself determined by considerations of geometry and reinforcement percentage. To contribute to a better understanding of the behavior of external beamcolumn joints made of high strength concrete a theoretical study based on the Non-linear finite element analysis is usually appropriate. ANSYS 10[17] software package was used to perform the analysis using the available Solid 65 3-D reinforced concrete element with reinforcing bars. 26 specimens were considered and analyzed. The main parameters were, the details, type and amount of joint reinforcement, the type and amount of beam and column main reinforcement in the joint, the level of axial column load and the concrete strength.The Obtained results were analyzed and discussed. The results were also compared with the obtained results using some available formulae found in the literature. Finally beneficial conclusions and some design recommendations were outlined and given.

KEYWORDS: joints, beam-column-connection, shear strength, high strength, concrete, joint reinforcement, R. C. frames.

\section{1- INTRODUCTION}

There is no doubt, that beam-column joints in R.C. ductile frames require special attention. Unless the designer possesses a good understanding of joint behavior and the reasons for possible unsatisfactory structural response an adequate design cannot be applied. Over the last 30 years, many theoretical and experimental research works have been carried out in several countries, which led to the identification of critical features of joint behavior. Recommendations for design, which are often empirical, were given in the different codes. In the recent years, there has been a rapid growth in the use of high strength concrete. However most of the previous works carried out so far for beam-column joints are for those made of normal strength concrete. A rational and 
simple design procedure for such connections especially when using high strength concrete, is still needed. The efficiency of using new non-conventional reinforcing pattern such as the use of fiber concrete or crossed inclined joint bars requires more researches.

Many parameters influence the strength and ductility of R.C connections including relative stiffness between beam and column, strength of concrete, type, quantity and detail of joint reinforcement and the column acting axial load. From the previous works, it can be shown that the strength of beam-column joint is limited by the following failure modes: joint shear failure of inadequate joints, column failure by forming plastic hinges in the column immediately above or below the beam in case of stiffer beams, beam flexural failure by forming plastic hinges (diagonal splitting failure, shear compression failure). The columns must remain essentially elastic throughout the load history to insure the lateral stability of the structure. At the same time, excessive joint shear deformation is irreversible and would cause permanent drift of the building [1-9].

Vollumn and Newman [3] in their study on external beam-column joints proposed an analytical model for the design and prediction of the strength of such connections. Tsonos et al [4] in their experimental investigation of external beamcolumn joints, found that inclined bars in the joint region improve their seismic resistance. Committee 352 [12] specifies maximum allowable joint shear stress for exterior joint of $0.96 \mathrm{~V} \mathrm{fcu}$. A lower limits of flexural strength ratio "MR" (the ratio of the sum of flexural capacity of columns to that of beam) in this case is confirmed to 1.4 .

The present investigation aims to provide some information towards better understanding and satisfactory improving the strength and ductility for such connections, especially when using high strength concrete. Using a theoretical analysis through the ANSYS 10[17] software package, stresses, strains, crack pattern at different load levels, and the failure load, were predicted. The available Solid 65 3-D reinforced concrete element with reinforcing bars is used. The solid element is capable to cracking in tension and crushing in compression.

\section{2- DETAILS OF CHOSEN EXTERNAL JOINTS AND ARRANGEMENT OF ACTING LOADS}

26 external R.C joints arranged in 5 series were analyzed. The description of various parameters considered in the study and the used program is summarized and given in table (1). The details of the joints are shown in Fig (1). The beam and the column for all specimens have the same cross section dimensions $25 \times 50 \mathrm{~cm}$. The main parameters taken into consideration are the concrete strength (Seri 1), the axial column load (Seri 2 ), the amount and type of extra horizontal top and bottom reinforcement at beam( Seri 4), the cross-bar reinforcement ratio at joint (Seri 5). The shear force was applied at the end of the beam and was incrementally increased up to failure, while, during each loading, the axial column load was kept constant at a certain value, which was less than 40 percent of the column ultimate axial load. The aim of subsequent loading was to trace the joint strength envelope. 
Table (1) Details of the chosen external joints

\begin{tabular}{|c|c|c|c|c|c|c|c|c|c|}
\hline $\begin{array}{c}\text { Series } \\
\text { No }\end{array}$ & $\begin{array}{l}\text { Join } \\
\text { t No }\end{array}$ & $\begin{array}{c}\mathbf{f}_{\mathrm{cu}} \\
\left(\mathbf{M}_{\mathrm{pa}}\right)\end{array}$ & $\begin{array}{c}\text { Column } \\
\text { axial } \\
\text { Load }(\mathbf{N}) \\
(\mathbf{K N})\end{array}$ & $\begin{array}{c}\mathbf{N} / \\
\mathbf{f}_{\mathrm{cu}} \mathbf{b t}\end{array}$ & $\begin{array}{c}\text { horial }^{\text {al }} \\
\text { stirr. } \\
\text { of Joint }\end{array}$ & $\begin{array}{l}\text { Beam } \\
\text { main } \\
\text { reinf } \\
\mu_{\mathrm{b}} \%\end{array}$ & $\begin{array}{l}\mathrm{Col}^{\mathrm{n}} \\
\operatorname{reinf}_{\mu_{\mathrm{c}} \%}\end{array}$ & $\begin{array}{c}\text { Extra } \\
\text { h. }^{\text {al }} \\
\text { beam } \\
\text { reinf } \mu_{h}\end{array}$ & $\begin{array}{c}\text { Extra\% } \\
\text { cross } \\
\text { Joint } \\
\text { steel }\end{array}$ \\
\hline \multirow{5}{*}{1} & $J_{11}$ & 20 & \multirow{5}{*}{800} & 0.32 & \multirow{5}{*}{108} & \multirow{5}{*}{0.67} & \multirow{5}{*}{1.3} & \multirow{5}{*}{-} & - \\
\hline & $J_{12}$ & 40 & & 0.16 & & & & & - \\
\hline & $J_{13}$ & 60 & & 0.11 & & & & & - \\
\hline & $J_{14}$ & 80 & & 0.08 & & & & & - \\
\hline & $J_{15}$ & 100 & & 0.064 & & & & & - \\
\hline \multirow{9}{*}{2} & $J_{21}$ & \multirow{3}{*}{20} & o.w.t & 0 & \multirow{3}{*}{108} & \multirow{3}{*}{0.67} & \multirow{3}{*}{1.3} & \multirow{3}{*}{-} & - \\
\hline & $J_{22}$ & & 200 & 0.08 & & & & & - \\
\hline & $J_{23}$ & & 400 & 0.16 & & & & & - \\
\hline & $J_{24}$ & \multirow{3}{*}{60} & o.w.t & 0 & \multirow{3}{*}{108} & \multirow{3}{*}{0.67} & \multirow{3}{*}{1.3} & - & - \\
\hline & $J_{25}$ & & 200 & 0.026 & & & & - & - \\
\hline & $J_{26}$ & & 400 & 0.055 & & & & - & - \\
\hline & $J_{27}$ & \multirow{3}{*}{100} & o.w.t & 0 & \multirow{3}{*}{$1 \emptyset 8$} & \multirow{3}{*}{0.67} & \multirow{3}{*}{1.3} & \multirow{3}{*}{ - } & - \\
\hline & $J_{28}$ & & 200 & 0.016 & & & & & - \\
\hline & $J_{29}$ & & 400 & 0.026 & & & & & - \\
\hline \multirow{4}{*}{3} & $J_{31}$ & \multirow{4}{*}{60} & \multirow{4}{*}{800} & 0.11 & \multirow{4}{*}{$3 \emptyset 8$} & 0.33 & \multirow[b]{2}{*}{1.3} & \multirow{4}{*}{ - } & - \\
\hline & $J_{32}$ & & & 0.11 & & 1.0 & & & - \\
\hline & $J_{33}$ & & & 0.11 & & & 2 & & - \\
\hline & $J_{34}$ & & & 0.11 & & 0.67 & 3 & & - \\
\hline \multirow{3}{*}{4} & $J_{35}$ & \multirow{3}{*}{60} & \multirow{3}{*}{800} & 0.11 & \multirow{3}{*}{$3 \emptyset 8$} & & & 0.2 & - \\
\hline & $J_{36}$ & & & 0.11 & & 0.67 & 1.3 & 0.4 & - \\
\hline & $J_{37}$ & & & 0.11 & & & & 0.67 & - \\
\hline & $J_{41}$ & 60 & 800 & 0.11 & $5 \emptyset 8$ & .67 & 1.3 & . & - \\
\hline & $J_{42}$ & & & 0.11 & $4 \emptyset 8$ & & & - & - \\
\hline 5 & $J_{51}$ & & & 0.11 & & & & - & 0.2 \\
\hline & $J_{52}$ & 60 & 800 & 0.11 & $3 \emptyset 8$ & 0.67 & 1.3 & - & 0.4 \\
\hline & $J_{53}$ & & & 0.11 & & & & - & 0.67 \\
\hline
\end{tabular}

\section{3- RESULTS AND ANALYSIS}

The obtained failure load, peak strains, joint shear stress at failure and the mode of failure are given in table (2). To confirm the obtained ANSYS results, the failure loads for the joints were predicted using some theoretical approaches and formulae found in the code and literature (11). The estimated values are included in table (2) and are plotted against the corresponding obtained results for analyzed beams in Fig (2), where a good agreement can be noticed. However, the code formulae over estimated the failure load for those joints failed by joint shear. 


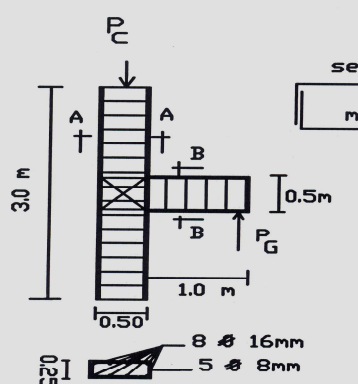

secondery steel

main steel
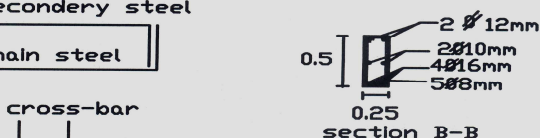

section A-A
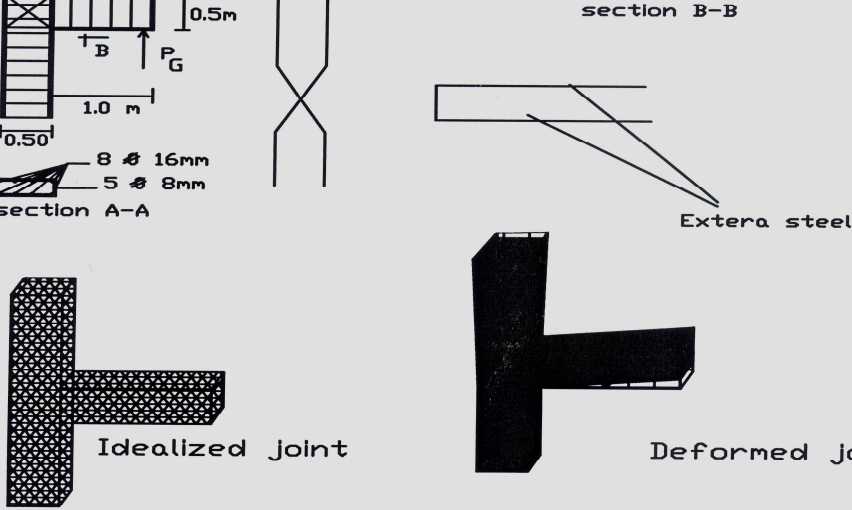

Idealized joint

Deformed joint

Fig (1) Details of external joint

4

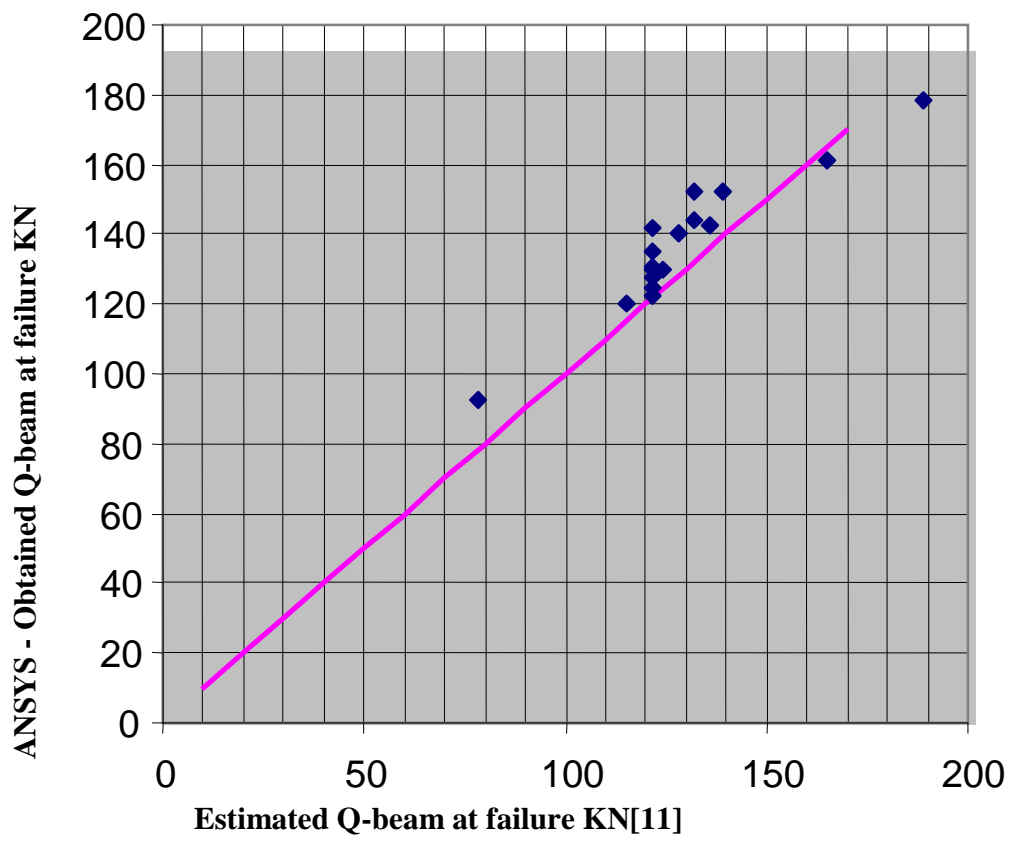

Fig (2) The obtained ANSYS results against the estimated failure load given in the available literature 


\section{Table (2) Some obtained and estimated results of the analyzed beams}

\begin{tabular}{|c|c|c|c|c|c|c|c|c|c|c|}
\hline 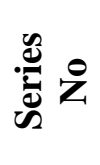 & $\begin{array}{c}\text { Joint } \\
\text { No }\end{array}$ & $\begin{array}{c}\mathbf{f}_{\mathrm{cu}} \\
\left(\mathbf{M}_{\mathrm{pa}}\right)\end{array}$ & $\begin{array}{c}\text { Column } \\
\text { Load Nc } \\
(\mathrm{KN})\end{array}$ & $\begin{array}{c}\mathbf{N c} / \\
\mathbf{f}_{\mathrm{cu}} \mathbf{b t}\end{array}$ & $\begin{array}{c}Q_{b f} \text { at } \\
\text { failure } \\
(K N)\end{array}$ & $\begin{array}{c}\mathbf{Q}_{\text {bf }} \\
\text { Esti- } \\
\text { mated } \\
(\mathbf{K N})\end{array}$ & 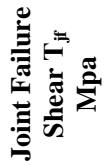 & $\begin{array}{c}\mathbf{T}_{\mathbf{j f}} / \\
\tau_{j, \max }\end{array}$ & $\begin{array}{c}\text { Mode of } \\
\text { failure }\end{array}$ & $\begin{array}{c}\text { Peak } \\
\text { strain } \\
\text { At joint }\end{array}$ \\
\hline \multirow{5}{*}{1} & $J_{11}$ & 20 & \multirow{5}{*}{800} & 0.32 & 50 & - & 0.95 & 0.25 & 3 & 0.0017 \\
\hline & $J_{12}$ & 40 & & 0.16 & 80 & - & 1.41 & 0.27 & 3 & 0.0018 \\
\hline & $J_{13}$ & 60 & & 0.11 & 120 & 115 & 2.1 & 0.33 & 3,2 & 0.0025 \\
\hline & $J_{14}$ & 80 & & 0.08 & 141 & 129 & 2.25 & 0.3 & 2 & -0.003 \\
\hline & $J_{15}$ & 100 & & 0.064 & 152 & 132 & 2.33 & 0.28 & 2 & -0.0028 \\
\hline \multirow{9}{*}{2} & $J_{21}$ & \multirow{3}{*}{20} & $o . w . t$ & 0 & 27.1 & - & 0.5 & 0.13 & 3 & 0.0015 \\
\hline & $J_{22}$ & & 200 & 0.08 & 34.5 & - & 0.62 & 0.17 & 3 & 0.0016 \\
\hline & $J_{23}$ & & 400 & 0.16 & 42 & - & 0.79 & 0.22 & 3 & 0.0016 \\
\hline & $J_{24}$ & \multirow{3}{*}{60} & o.w.t & 0 & 68.8 & - & 1.2 & 0.18 & 3 & -0.0019 \\
\hline & $J_{25}$ & & 200 & 0.026 & 86.4 & - & 1.5 & 023 & 3 & -0.0018 \\
\hline & $J_{26}$ & & 400 & 0.055 & 103 & - & 1.76 & 028 & 3 & -0.0017 \\
\hline & $J_{27}$ & \multirow{3}{*}{100} & o.w.t & 0 & 107 & - & 1.74 & 021 & 3 & 0.0032 \\
\hline & $J_{28}$ & & 200 & 0.016 & 130 & 124 & 2.24 & 0.27 & 2 & 0.0051 \\
\hline & $J_{29}$ & & 400 & 0.026 & 144 & 132 & 2.3 & 0.29 & 2 & 0.005 \\
\hline \multirow{4}{*}{3} & $J_{31}$ & \multirow{4}{*}{60} & \multirow{4}{*}{800} & 0.11 & 92.2 & 78 & 1.02 & 0.16 & 2 & -0.0031 \\
\hline & $J_{32}$ & & & 0.11 & 152 & 139 & 2.62 & 0.41 & 2 & -0.0027 \\
\hline & $J_{33}$ & & & 0.11 & 124.8 & 122 & 2.17 & 0.34 & 2 & -0.0032 \\
\hline & $J_{34}$ & & & 0.11 & 127.3 & 122 & 2.25 & 0.37 & 2 & -0.0034 \\
\hline \multirow{3}{*}{4} & $J_{35}$ & \multirow{3}{*}{60} & \multirow{3}{*}{800} & 0.11 & 142.9 & 136 & 2.5 & 0.38 & 2 & 0.0041 \\
\hline & $J_{36}$ & & & 0.11 & 160.9 & 165 & 2.95 & 0.46 & 1.2 & 0.0037 \\
\hline & $J_{37}$ & & & 0.11 & 178 & 189 & 3.52 & 0.56 & 1,2 & 0.0028 \\
\hline \multirow{5}{*}{5} & $J_{41}$ & \multirow[t]{2}{*}{60} & \multirow[t]{2}{*}{800} & 0.11 & 130 & 122 & 2.24 & 0.35 & 2 & 0.0042 \\
\hline & $J_{42}$ & & & 0.11 & 128 & 122 & 2.16 & 0.34 & 2 & 0.0041 \\
\hline & $J_{61}$ & \multirow{3}{*}{60} & \multirow{3}{*}{800} & 0.11 & 122.5 & 122 & 1.8 & 0.28 & 2 & 0.0035 \\
\hline & $J_{62}$ & & & 0.11 & 130.4 & 122 & 1.33 & 0.21 & 2 & 0.0038 \\
\hline & $J_{63}$ & & & 0.11 & 142 & 122 & 1.06 & 0.17 & 2 & 0.0042 \\
\hline
\end{tabular}

1. Shear failure of beam (diagonal failure).

2. Beam flexural failure (plastic hinge)..

3. Joint shear failure (diagonal splitting failure).

+ positive strain.

- Negative strain.

The obtained results are summarized in table [2] were analyzed to declare the effect of various included parameters in this study as follows: -

\section{3-1-Effect of Concrete Strength FCU and Column Axial Load:-}

The joint shear stresses at failure " $\tau_{j f}$ " for beams with different " $f_{c u}$ " and the same amount of reinforcement in sere "1" are plotted against the concrete compressive 
strength in Fig (3). It can be seen that increasing the concrete compressive strength increased the joint shear stress at failure. This increase was rapid and almost linear up to a limit of $f_{c u}=$ about $60 \mathrm{mpa}$, after which a negligible increase in the joint shear failure occurred. Beyond this limit the mode of failure was changed from joint shear failure to a beam flexural failure for higher values of $f_{c u}$, and so the failure load was limited not only by concrete strength, but also by the amount of tension reinforcement. This led to a reduction in the value of $\tau_{j f} / \tau_{j, \max }$ in the first Series for joints $\mathrm{j}_{14}, \mathrm{j}_{15}$.

\section{$\mathrm{Nc}=800 \mathrm{KN}$}
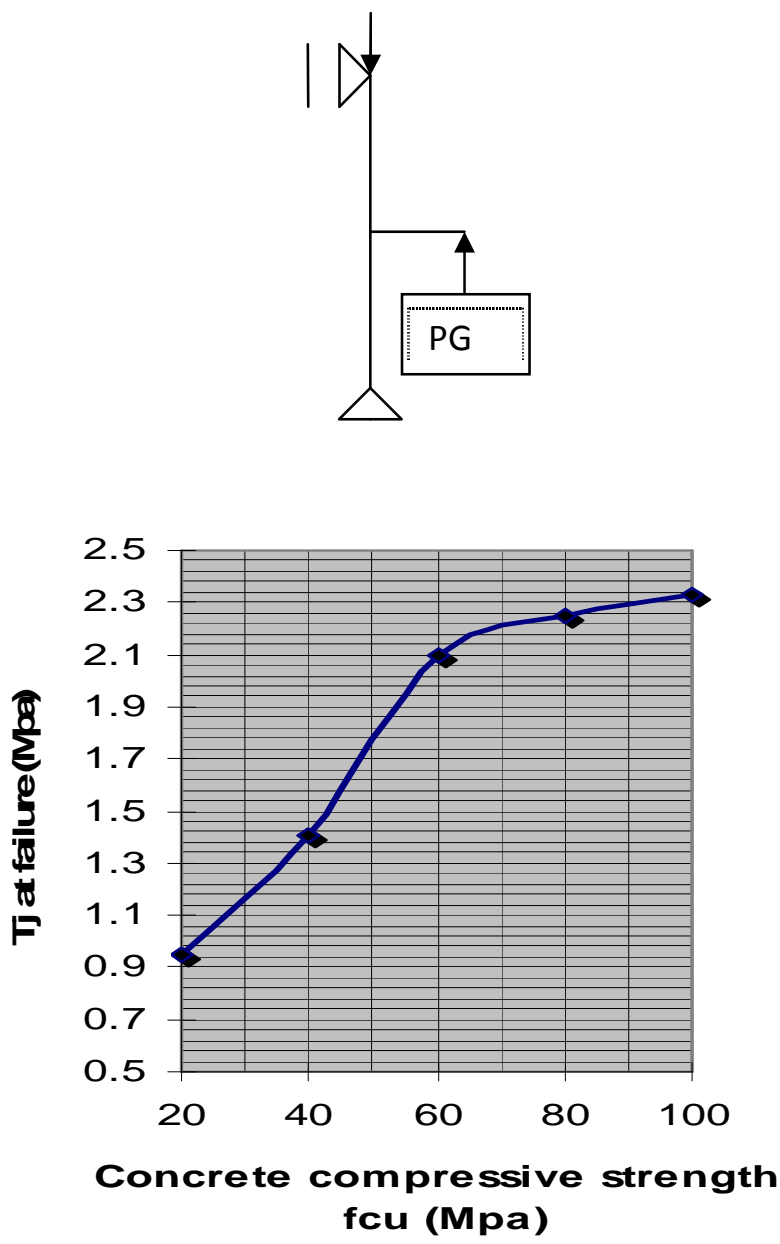

Fig (3) $\tau$ jf versus fcu under axial force $\mathrm{Nc}=800 \mathrm{KN}$

In Fig (4) the effect of column axial load on the joint shear stress at failure, for different concrete compressive strength, beams in sere "2", is shown. It can be seen, from this Fig and from table (2) that, axial compression load on columns up to the studied level (about 40 percent of the column balanced axial load) beneficially influences the shear resistance of joints. Increasing the axial column load, for the 
different concrete compressive strength, increased both the joint failure load and joint shear stress at failure. The mode of failure was also changed from the joint shear failure to flexural beam failure in beams j13, j14, j15, j28 and j29 with higher concrete compressive strength.

Figure (5) shows the relation between concrete compressive strength, axial column load and beam failure load, Increasing the concrete compressive strength under different axial loads leads to increasing the failure load for beam.

Figure (6) shows the relation between joint shear stress at failure and the level of axial compression force on column for beams with constant axial force and different fcu, beams in sere "1". With increasing the concrete compressive strength under constant axial load, the level of axial force "Nc/fcubt" decreased, and so the joint shear stress increased.

The obtained peak strains at for beams in series "1, 2" were small in comparison with beams of other series, which reflects the brittle behavior of theses beams failed by joint shear. Also the occurred joint stresses at failure for these beams had not reached the maximum allowable joint shear stress for exterior joint specified by the code due to the insufficient transverse reinforcement in the joint region.

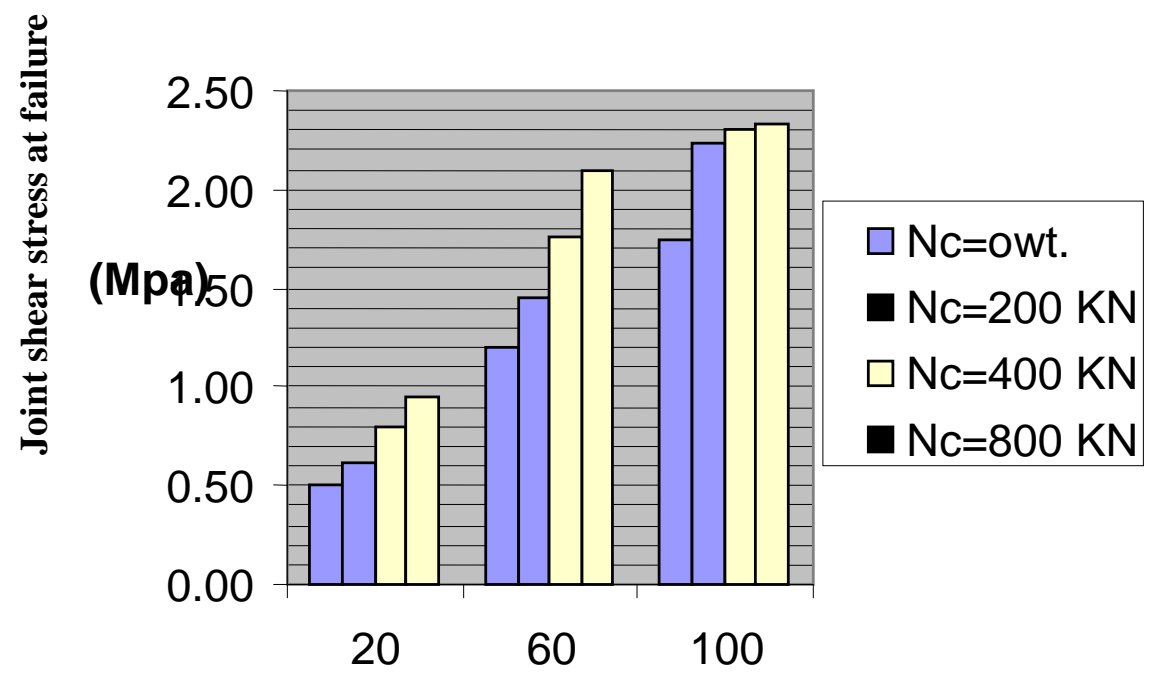

Concrete compressive strength (Mpa)

Fig (4) Relation between concrete compressive strength, Axial column load and joint shear stress at failure 


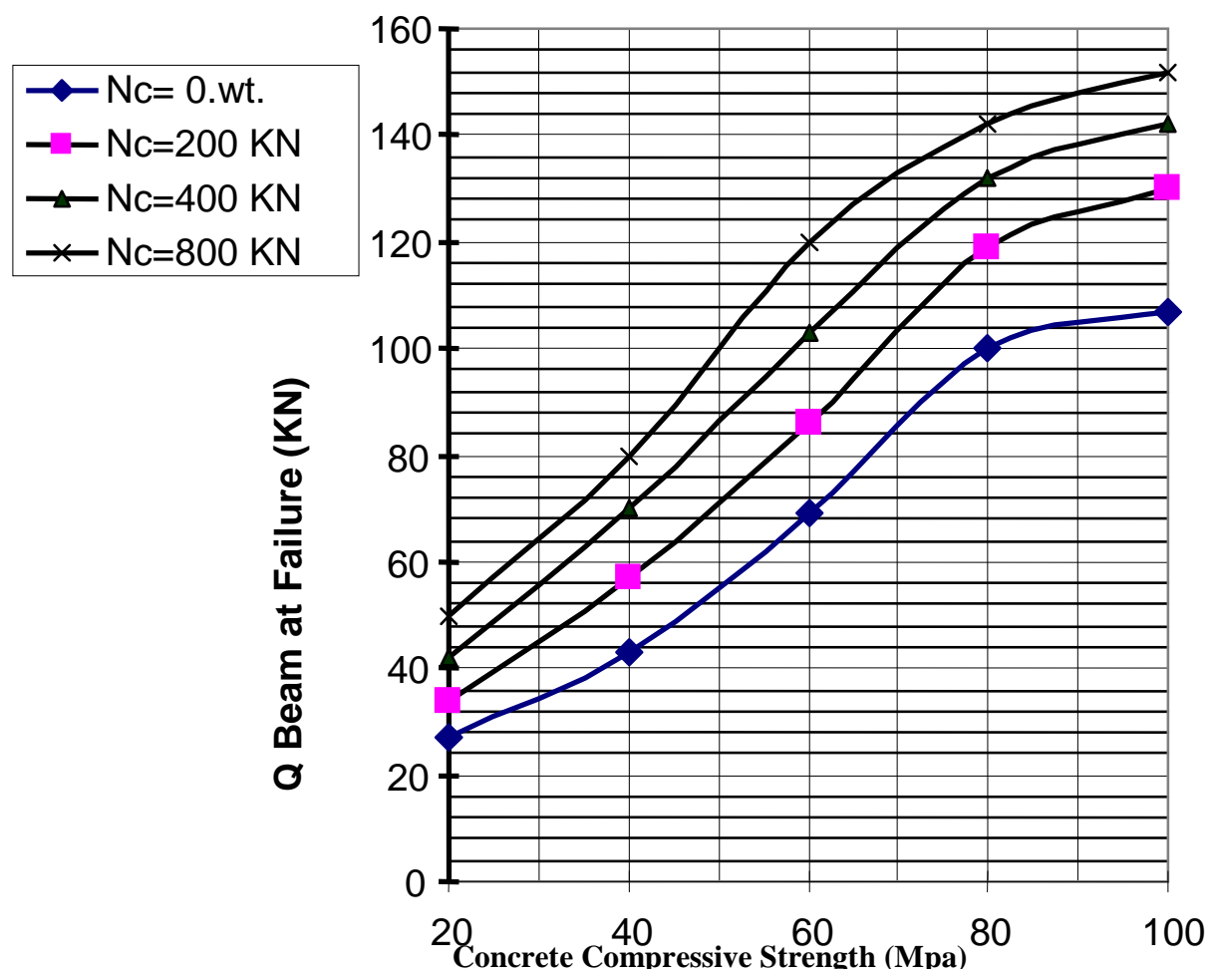

Fig (5) Relation between concrete compressive strength, Axial column load and beam failure load

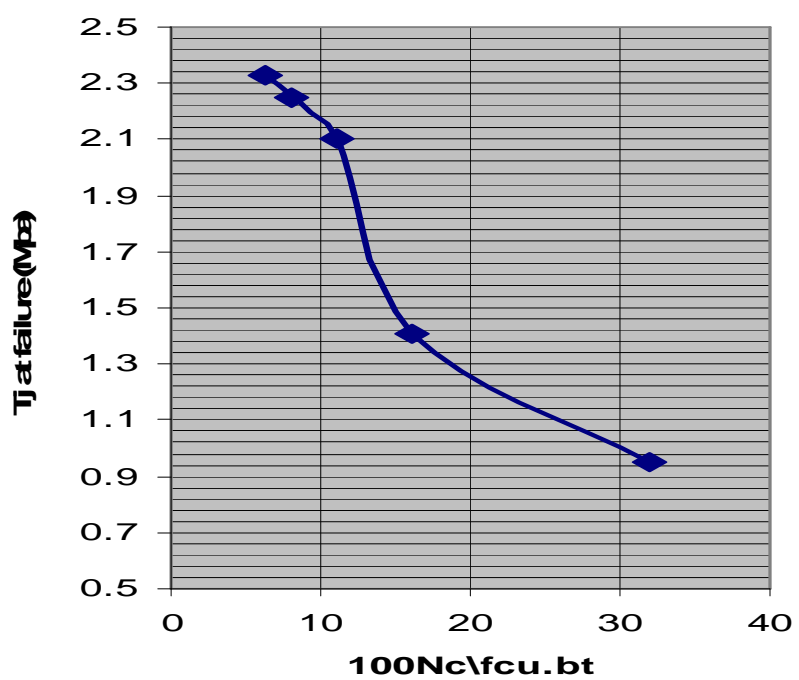

Fig (6) the relation between the column axial load level and joint shear stress at failure under constant $\mathrm{Nc}$ and different fcu 


\section{3-2 Effect of Joint Reinforcement:-}

The lack of adequate transverse confining steel for concrete in the joint region led to a smaller failure load and a brittle shear failure of joint. This type of failure prevents the ultimate strength of connecting beam and columns to be developed, see results for beams $\mathrm{j} 11, \mathrm{j} 12$, j21-j27, in series 1,2 , in table (2). The presence of sufficient transverse reinforcement changed the mode of failure from being joint shear failure to a beam flexural failure, which led to an increase in the failure load, beams in series 3,4, table (2). The increase in the horizontal top and bottom joint reinforcement extended from the beam reinforcement, with the presence of sufficient transverse joint stirrups, increased significantly the ultimate load and the joint shear stress at failure, Fig (7). However, a further increase in the transverse joint reinforcement had a negligible effect on the ultimate strength of the joint as it was limited by the beam flexural failure, beams of seri "4".

The use of X-bars in the joint region for the tested beams was not so effective as the horizontal reinforcement. However, the joint shear stress at failure decreased in spite of the no decreased failure load. The inclined bars participate in resisting the joint shear force, which release the stress on the joint core. The increase of column main steel reinforcement showed a negligible effect on the failure load of the tested specimens. This can be attributed to the type of the failure mode, which was a beam failure. However the presence of the X-bars in the joint region and increasing the column main reinforcement slightly reduce the deformation prior to failure.

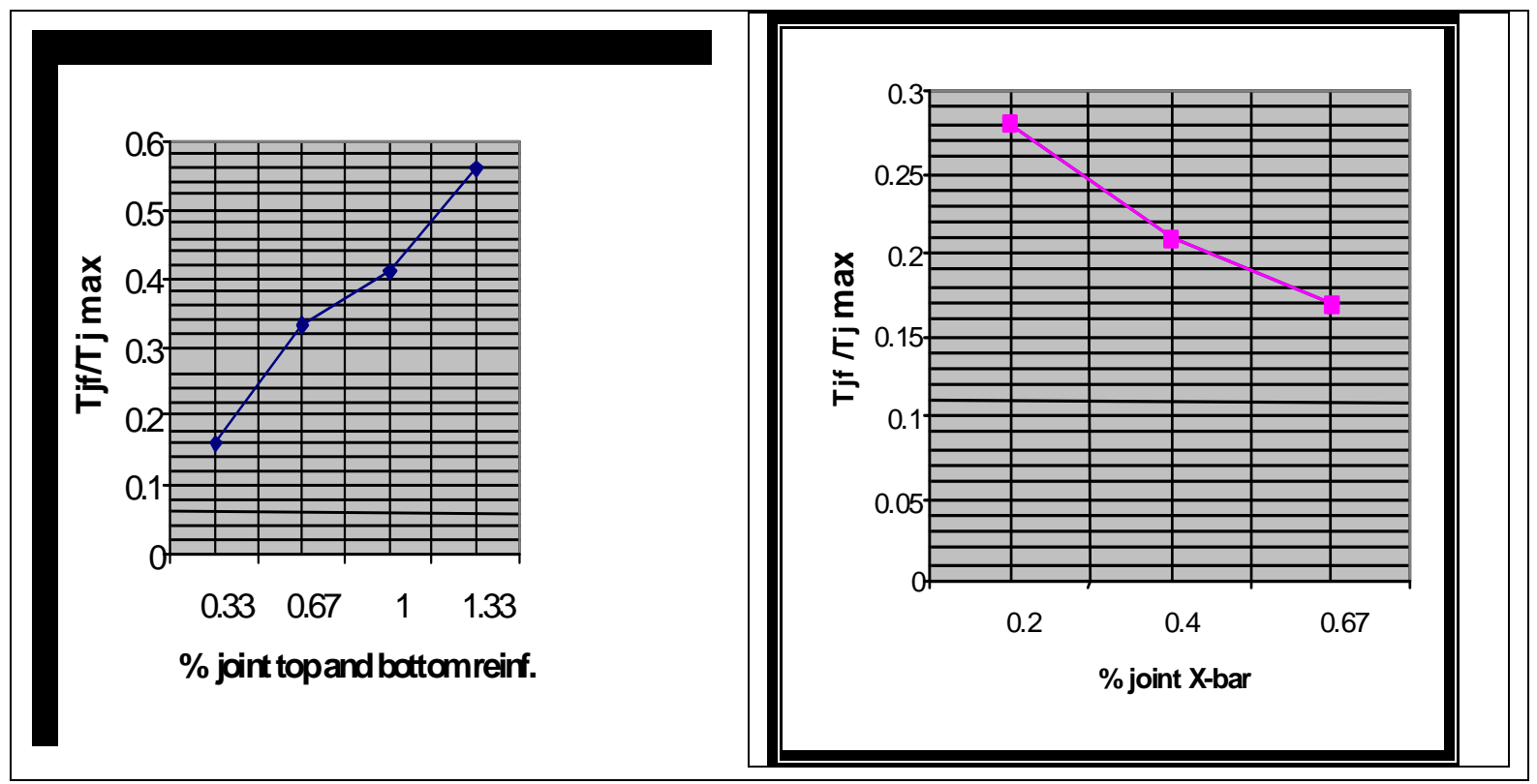

Fig (7) Effect of joint top and bottom Reinforcement as well as joint X-bars reinf.

On joint shear stress ratio " $\tau \mathrm{jf} / \tau \mathrm{j}$, $\max$ " at failure 


\section{4- CONCLUSIONS AND RECOMMENDATIONS}

- The lack of adequate transverse steel and confinement of concrete in the joint region led to a brittle shear failure of joint, which prevented the aimed ultimate strength of connecting beam and columns to be developed.

- The presence of transverse reinforcement in the joint considerably improves the connection behavior leading to an increase the failure load, the joint shear stress at failure and the overall deformation capacity of the joint.

- Connections, in which the flexural hinges are formed out side the joint exhibit more stable and ductile behavior than those for which the failure occurs in the joint region itself.

- Increasing the axial column load up to the chosen level (about 40 percent the column balanced axial load) beneficially influences the shear resistance of joints.

- Increasing the concrete compressive strength leads to an increase the joint shear resistance and deformation capacity.

- The code formulae [11] seem to overestimate the joint shear stress at failure for beams with high concrete compressive strength.

- More researches are required on RC frame joints made of high strength concrete to cover the full range for various parameters influencing the behavior of such joints either external or internal joints.

\section{NOTATIONS}

$\mathrm{N}_{\mathrm{c}}$ : The axial compression force on column "KN"

$\mathrm{Q}_{b f}$ : The applied shear on the beam at failure "KN"

$\mathrm{Q}_{i f}$ : joint shear force due to $\mathrm{Q}_{\mathrm{b}}$ at failure "KN"

$\tau_{j f}:$ The joint shear stress at failure mpa

$\tau_{j, \max }:$ maximum allowable joint shear stress for exterior joint $=0.96 \sqrt{ } f_{c u} / \gamma$

$\mu_{b}$ : The percentage of the main reinforcement in the beam

$\mu_{c}$ : The percentage of column reinforcement

$f_{c u}$ : characteristic compressive strength of concrete mpa

\section{REFERENCES}

1. Uma S. R., Meher Prasad A.: Analytical model for beam column joint in RC frames under seismic conditions. Journal of Structural Engineering V. 30, No, 3 , Oct.-Dec, 2003, 163 - 170

2. Scott R. H., FIStructE : A preliminary investigation of strains in reinforced concrete beam - column connections due to seismic loading. Magazine of Concrete Research, 1991, 43, No. 154, Mar., 59 - 64

3. R. L. Vollum and J. B. Newman : Towards the design of reinforced concrete eccentric beam - column joints. Magazine of Concrete Research, 1999, 51, No. 6, Dec., $396-407$ 
4. Tsonos A. G., Tegos I. A., and Penelis G. Gr. : Seismic Resistance of type 2 Exterior Beam-Column Joints Reinforced with Inclined Bars. ACI Structural Journal, V. 89, No. 1, January-February 1992, 3 - 12

5. Sungjin Bae and Oguzhan Bayrak "Stress Block Parameters for High-Strength Concrete Members" ACI Structural Journal, V. 100, No. 5, Sep.-Oct. 2003, 626 636

6. Thomas Paulay : Equilibrium Criteria for Reinforced Concrete Beam-Column Joints. ACI Structural Journal, V. 86, No. 6, Nov. Dec. 1989, 635 - 643

7. Scott R. H.: The effects of detailing on RC beam - column connection behavior. The Structural Engineering, 1992, 70, No. 18, 318 - 324

8. Roberto T. Leon "Shear Strength and Hysteretic Behavior of Interior BeamColumn Joints" ACI Structural Journal, V. 87, No. 1, January-February 1990, 3 11

9. Ehsani M. R. and Wight J. K. "Effect of transverse Beams and slabs on Behavior of Reinforced Concrete Beam-to-Column Connections" ACI Structural Journal, March-April 1985,188-195.

10. Daniel P. Abrams "Scale Relations for Reinforced Concrete Beam-Column Joints" ACI Structural Journal, Nov. Dec. 1987, 502 - 512

11. ACI Committee 318-95, "Building Code Requirements for Structural Concrete and Commentary" Farmington Hills, Michigan,2004, part 4.

12. ACI-ASCE Committee 352R-91. Recommendations for the design of beam column joints in monolithic reinforced concrete structures. ACI Manual of Concrete Practice, American Concrete Institute, Detroit, 1998, Part 3.

13. BRITSH STANDARDS INSTITUTION. Design Concrete Structures :Part 1:General Rules for BUILDINGS BSI.MILTON Keynes,2006 Euro code 2.

14. PARKER D. E. and BULLMAN P. J.M Sear strength within reinforced beamcolumn joints. The Structural Engineer, 2004,75, No 4,53-57.

15. Restrepo, J.I.,and Lin, C.M., "Evaluation of shear strength Of Beam-Column Joints of Reinforced Concrete Frames Subjected to Earthquake Loading" Auckland, New Zealand, Paper .522,2000.

16. Baglin, P.S., and Scott, R.H., Nov., "Finite Element Modeling of Reinforced Concrete Beam-Column Connection " ACI Structural Journal, Vol.97,2000.

17. ANSYS User's Manual, 2008, Teory,Commands, Analsis and Element, Release 10 ANSYS Inc.Houston,Pa., 2008.

18. ANSYS User's Manual, 2010, Teory,Commands, Analsis and Element, Release 12 ANSYS Inc.Houston,Pa., 2010. 


\section{أداء الوصلة الخارجية للعامود والكمرة المصنوعة من خرسانة عالية المقاومة}

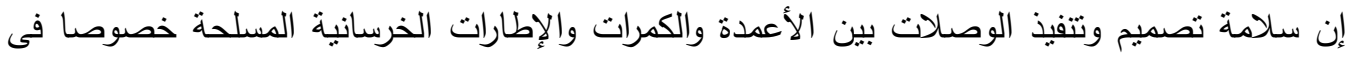

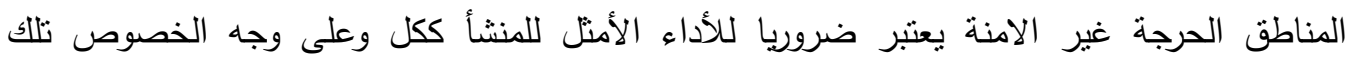

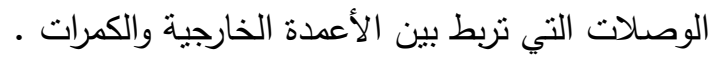
ووجد أهم العوامل المؤثرة في هذا الأداء هي مقاومة الخرسانة المنفذة و حديد نسليح الوصلة والجساءه واءه

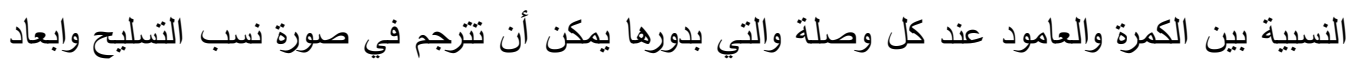

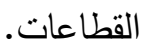

ولمحاولة فهم افضل للوصلات الخارجية للعامود والكمرة المصنوعة من خرسانة عالية المقاومة اجرية هذه الدراسة النظرية باستخدام برنامج (ANSYS 10) حيث تم اعتبار 26 وصلة تختلف في تفاصيل ونوع وكمية حديد التسليح الوصلة وتسليح كل من الكمرة والعامود ومقدار قوة الضغط المحوري المؤثرة على العامود ومقاومة الخرسانة المنفذة.

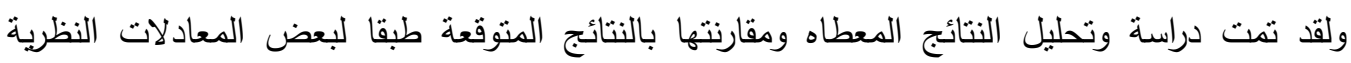

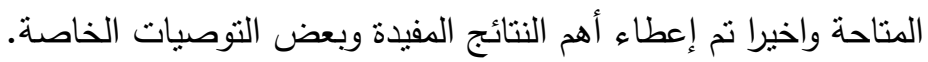

